\title{
Aktivitas Antimikroba Teh Asam Daun Tin (Ficus carica) Secara In Vitro
}

\author{
Elwin Dwi Novitasari, Ernanin Dyah Wijayanti \\ Akademi Farmasi Putra Indonesia Malang \\ Email: nanin.wijayanti@gmail.com
}

\begin{abstract}
Abstrak
Daun tin mengandung flavonoid yang dapat digunakan sebagai antimikroba. Fermentasi dengan kombucha diharapkan dapat meningkatkan aktivitas antimikroba. Penelitian ini bertujuan untuk mengetahui potensi teh asam daun tin sebagai antimikroba terhadap beberapa mikroba, diantaranya Staphylococcus aureus, Escherichia coli, Lactobacillus casei dan Candida albicans. Teh asam dibuat melalui fermentasi seduhan daun tin dengan bantuan kombucha selama 12 hari. Uji antimikroba dilakukan dengan menggunakan metode difusi sumuran. Dari hasil pengujian diperoleh rerata zona hambat terhadap Escherichia coli 6,97 $\mathrm{mm}$, Staphylococcus aureus 5,5 mm, Lactobacillus casei 5,29 mm, dan Candida albicans 0,37 mm. Berdasarkan hasil penelitian teh asam daun tin berpotensi sebagai antimikroba, terutama sebagai antibakteri.
\end{abstract}

Kata Kunci: Antimikroba, Daun Tin, Fermentasi, Flavonoid, dan Kombucha.

\begin{abstract}
Fig Leaves contain flavonoids that can be used as antimicrobials. Fermentation with kombucha is expected to increase antimicrobial activity. The aim of this research is to observe antimicrobial activity of Fig Leaves sour tea against several microbes, such as Staphylococcus aureus, Escherichia coli, Lactobacillus casei and Candida albicans. The sour tea is made through 12 days fermentation of Fig Leaves with kombucha. Antimicrobial assay has been performed using the agar well diffusion method. From the test results, the mean of inhibition zone against Escherichia coli is 6,97 mm. Staphylococcus aureus is 5,5 mm, Lactobacillus casei is 5,29 mm, and Candida albicans is 0,37 mm. Based on the research results, Fig Leaf sour tea can be used as an antimicrobial agent, especially as an antibacterial.
\end{abstract}

Key words: Antimicrbial, Fig Leaf, Fermentation, Flavonoids, and Kombucha.

\section{PENDAHULUAN}

Penyakit infeksi merupakan suatu penyakit yang disebabkan karena adanya mikroba patogen. Menurut Kemenkes RI pada tahun 2016 telah terjadi kasus penyakit infeksi hingga mencapai 7 juta kasus. Untuk mengobati penyakit infeksi ini, biasanya digunakan antibiotik atau antimikroba. Namun, karena antibiotik atau antimikorba telah digunakan secara luas dan berlebihan, menyebabkan terjadinya resistensi mikroba.
Resistensi dapat mengakibatkan kecacatan bahkan kematian. Oleh karena itu fenomena resistensi ini mendorong peneliti untuk menemukan antimikroba dari tanaman herbal yaitu daun tin. Beberapa peneliti telah membuktikan bahwa daun tin memiliki aktivitas sebagai antimikroba. Menurut Jeong et al. (2009), senyawa flavonoid yang terkandung dalam daun tin yang memiliki aktivitas antimikroba. 
Pada umumnya masyarakat masih menggunakan cara empiris dalam mengolah tanaman herbal tersebut, misalnya hanya dengan cara rebusan atau seduhan. Untuk membuat teh asam daun tin, daun tin akan diekstrak dengan metode seduhan. Namun karena hasil dari seduhan ini terasa pahit maka harus dilakukan proses yang dapat menghilangkan rasa pahit tersebut, yaitu fermentasi. Menurut Witoyo et al., (2015) tujuan dari fermentasi adalah untuk membentuk rasa atau aroma teh menjadi lebih khas atau enak. Menurut Megama (2016), fermentasi juga dapat memecah senyawa kompleks menjadi lebih sederhana. Daun tin mengandung senyawa flavonoid yang tergolong dalam polifenol kompleks. Melalui proses fermentasi, senyawa tersebut diharapkan dapat dipecah menjadi lebih sederhana dan mengalami peningkatan bioaktivitas. Hur et al. (2014) menyatakan bahwa fermentasi dapat meningkatkan pelepasan zat aktif sehingga meningkatkan bioaktivitasnya. Fermentasi dapat meningkatkan senyawa fenolik pada sari buah tin (Wijayanti et al., 2017) dan ketersediaan flavonoid (rutin) sari buah tin (Wijayanti and Setiawan, 2017) dan meningkatkan aktivitas antioksidan sari rimpang temu giring (Yustin dan Wijayanti, 2018).

Salah satu fermentasi yang dapat diaplikasikan adalah menggunakan kombucha. Nurmiati dan Wijayanti (2018) menyatakan bahwa fermentasi kombucha dapat meningkatkan kadar senyawa fenolik pada daun gaharu. Kombucha merupakan lapisan gelatin dan terlihat seperti nata, berbentuk piringan datar (Rinihapsari, 2008). Menurut Naland (2008) kultur kombucha memiliki bentuk lembaran tipis setebal $0,3-1,2 \mathrm{~cm}$ terlihat seperti gelatin warna putih. Kombucha juga memiliki manfaat sebagai antimikroba. Menurut Velicanski et al. (2014), komponen aktif yang dominan sebagai antimikroba pada kombucha adalah asam asetat. Semakin tinggi keasaman maka zona hambatnya semakin besar. Berdasarkan hal tersebut, fermentasi menggunakan kombucha diharapkan akan meningkatkan aktivitas antimikroba. Berdasarkan uraian diatas perlu dilakukan penelitian mengenai potensi aktivitas antimikroba dari teh asam daun tin. Penelitian ini dilakukan secara in vitro dengan metode difusi sumuran menggunakan mikroba uji berupa flora normal tubuh Staphylococcus aureus, Escherichia coli, dan Candida albicans, serta Lactobacilus casei.

\section{METODE PENELITIAN}

Penelitian ini menggunakan daun tin dari spesies Ficus carica yang diperoleh dari Kecamatan Poncokusumo Kabupaten Malang. Simplisia daun tin sebanyak 7 gram diseduh dengan air panas dengan suhu $\pm 100^{\circ} \mathrm{C}$ selama $10-15$ menit kemudian ditambahkan gula $10 \%$ (b/v) dan difermentasi dengan kultur kombucha selama 12 hari. Identifikasi flavonoid dilakukan terhadap seduhan dan teh asam daun tin, menggunakan uji reaksi warna. Pengujian aktivitas antimikroba dilakukan dengan metode difusi sumuran menggunakan media Mueller Hinton Agar (MHA, Oxoid), dengan penambagan glukosa $2 \%$ untuk pengujian antifungi. Mikroba indikator yang digunakan antara lain biakan murni Staphylococcus aureus (dikultur pada media Manitol Salt Agar/MSA, Oxoid), Escherichia coli (Eosin Methylene Blue Agar/EMBA, Oxoid), Lactobacillus casei (de Mann Rogosa Sharpe Agar/MRSA, Oxoid), dan Candida albicans (Saboraud Dextrose Agar, Oxoid). Masingmasing mikroba uji dibuat suspensi dengan larutan $\mathrm{NaCl} 0,9 \%$ dan diukur kekeruhannya dengan spektofotometer UV-Vis sinar tampak (Genesis 2.0) pada panjang gelombang $600 \mathrm{~nm}$ untuk bakteri dan $580 \mathrm{~nm}$ untuk fungi. Hasil absorbansi disesuaikan dengan standart Mc Farland 0,5 dengan nilai absorbansi 0,08-0,13.

\section{HASIL DAN PENELITIAN}

\section{Fermentasi Daun Tin}

Seduhan daun tin mengalami perubahan organoleptis setelah proses fermentasi menggunakan kombucha. Perubahan terjadi pada parameter warna, aroma dan rasa. Hasil pengujian organoleptis dapat dilihat pada Tabel 1. 
Tabel 1. Hasil Uji Organoleptis pada Seduhan dan Teh Asam Daun Tin.

\begin{tabular}{lcc}
\hline Parameter & Seduhan & Teh Asam \\
\hline Warna & Coklat tua & Coklat muda \\
\hline Aroma & Khas daun tin & $\begin{array}{c}\text { Khas daun tin dan } \\
\text { kombucha }\end{array}$ \\
\hline Tekstur & Encer & Encer \\
\hline Rasa & Pahit & Asam manis \\
\hline
\end{tabular}

Aroma yang dihasilkan pada teh asam daun tin yang telah dibuat yaitu perpaduan khas dan tin dan kombucha. Menurut Widyasari, (2016), semakin lama fermentasi aroma yang dihasilkan kombucha akan semakin meningkat disebabkan khamir dan bakteri melakukan metabolisme terhadap sukrosa dan menghasilkan sejenis asam. Aroma yang dihasilkan oleh kombucha disebabkan karena adanya asam-asam organik. Menurut Suhardini dkk. (2016), asam organik pada kombucha antara lain asam asetat, asam glukoronat, dan asam glukonat serta alkohol yang memberikan aroma yang khas.

Rasa yang dihasilkan dari fermentasi pada seduhan daun tin yaitu asam manis. Seperti halnya pada parameter aroma, perubahan rasa menjadi asam juga disebabkan oleh adanya proses metabolisme terhadap sukrosa yang menghasilkan sejumlah asam-asam organik seperti asam asetat, asam glukoronat dan asam glukonat.

\section{Identifikasi Fitokimia Senyawa Flavonoid}

Identifikasi fitokimia senyawa flavonoid dilakukan untuk memastikan bahwa proses fermentasi tidak menyebabkan senyawa yang dibutuhkan menjadi hilang. Identifikasi dilakukan menggunakan metode kualitatif dengan tujuan untuk mengetahui keberadaan senyawa flavonoid yang diduga sebagai antimikroba. Adanya senyawa flavonoid ditandai dengan perubahan warna kuning jingga setelah penambahan $\mathrm{HCl}$ pekat dan Serbuk $\mathrm{Mg}$ setelah dikocok (Djamil dan Winarti, 2014). Hasil identifikasi seduhan daun tin dan setelah proses fermentasi daun tin positif mengandung flavonoid golongan flavon karena hasil warna menunjukkan warna kuning jingga (Djamil dan Winarti, 2014).

\section{Aktivitas Antimikroba Teh Asam Daun Tin}

Pada penelitian ini mikroba uji yang digunakan adalah Staphylococcus aureus, Escherichia coli, Lactobacillus casei, dan Candida albicans. Seluruh mikroba yang digunakan merupakan flora normal di dalam tubuh manusia dan juga mewakili masing-masing kelompok yaitu Staphylococcus aureus mewakili bakteri Gram positif, Escherichia coli mewakili bakteri Gram negatif, Lactobacillus casei mewakili bakteri baik, dan Candida albicans mewakili golongan fungi.

Pengujian antimikroba dilakukan dengan menggunakan metode difusi sumuran. Diameter zona hambat sebagai indikator kekuatan aktivitas antimikroba, diukur menggunakan jangka sorong.

Tabel 2. Hasil Diameter Zona Hambat.

\begin{tabular}{l|c|c|c}
\hline \multirow{2}{*}{\multicolumn{1}{c|}{ Mikroba }} & \multicolumn{3}{|c}{$\begin{array}{c}\text { Diameter Zona } \\
\text { Hambat }(\mathrm{mm})\end{array}$} \\
\cline { 2 - 4 } & I & III & Rerata \\
\hline Staphylococcus aureus & 5,46 & 5,54 & 5,5 \\
\hline Escherichia coli & 7,64 & 6,30 & 6,97 \\
\hline Lactobacillus casei & 4,72 & 5,86 & 5,29 \\
\hline Candida albicans & 0,74 & 0 & 0,37 \\
\hline
\end{tabular}

Hasil penelitian pengujian aktivias antimikroba menunjukkan bahwa teh asam daun tin memiliki potensi aktivitas antimikroba dilihat dari diameter zona hambat yang terbentuk di sekitar sumuran. Adanya zona hambat pada sekitar sumuran karena metode difusi yang dapat menyebarkan senyawa aktif yaitu flavonoid. Menurut Ahaddin (2014), kandungan terbesar yang ada dalam tanaman tin adalah flavonoid. Penelitian oleh Ahaddin (2014) mengenai hasil uji kualitatif kandungan flavonoid menunjukkan adanya flavonoid berupa flavon dan flavonol. Adanya senyawa flavon pada uji kualitatif ditunjukkan dengan terbentuknya warna kuning jingga (Djamil 
dan Winarti, 2014). Menurut pernyataan Savoia (2012), flavon dan turunannya merupakan senyawa yang dapat digunakan sebagai terapi antibakteri dengan cara mengganggu dinding sel. Selain itu, flavonoid juga dapat digunakan sebagai antifungi (Wijayanti dan Susilowati, 2017). Menurut Freiesleben and Jager (2014), flavonoid mampu mengganggu homeostasis mitokondria tanpa menyebabkan peningkatan level ROS intraseluler dan tidak melibatkan apoptosis.

Berdasarkan data pada tabel 2 dapat diketahui adanya perbedaan diameter zona hambat terhadap masing-masing mikroba. Semakin besar diameter zona hambat maka semakin besar aktivitas antimikroba. Menurut Li et al. (2017), beberapa faktor dapat mempengaruhi aktivitas antimikroba, antara lain status bakteri (tingkat sensitivitas), konsenstrasi antimikroba dan faktor inang (untuk uji in vivo). Zona hambat terhadap Staphylococcus aureus, Lactobacillus casei dan Candida albicans lebih rendah dibandingkan dengan bakteri Escherichia coli. Hal ini dapat disebabkan struktur dan komposisi pada bakteri Escherichia coli berbeda dengan yang lainnya. Escherichia coli merupakan bakteri golongan Gram negatif, dimana bakteri Gram negatif memiliki struktur dinding sel yang lebih tipis dibandingakan dengan bakteri Gram positif sehingga senyawa antimikroba akan lebih mudah masuk ke dalam membran sel dan merusak sel bakteri Gram negatif (Khairunnisa dan Pato, 2016). Berbeda dengan Staphylococcus aureus dan Lactobacillus casei yang tergolong dalam Gram positif maka memiliki peptidoglikan lebih tebal pada dinding selnya, yang penting untuk pertahanan sel dan pertumbuhan (Romaniuk and Cegelski, 2015). Sedangkan zona hambat yang kecil terhadap Candida albicans menunjukkan tingkat sensitivitasnya yang rendah terhadap teh asam daun tin. Hal tersebut menunjukkan bahwa teh asam daun tin lebih berpotensi sebagai antibakteri dari pada sebagai antifungi.

\section{KESIMPULAN}

Berdasarkan hasil penelitian yang dilakukan menunjukkan bahwa teh asam daun tin memiliki aktivitas antimikroba, dengan kekuatan yang berbeda-beda terhadap mikroba uji. Teh asam daun tin menunjukkan potensi yang lebih baik sebagai antibakteri dari pada sebagai antifungi.

\section{DAFTAR PUSTAKA}

Ahaddin, A.Y. 2014. Isolasi Dan Sitotoksisitas Ekstrak Flavonoid Daun Tin (Ficus carica Linn.). Skripsi. Bogor: Institut Pertanian Bogor.

Djamil, R. \& W. Winarti. 2014. Identifikasi Senyawa Flavonoid dalam Fase n-Butanol Dari Ekstrak Metanol Daun Mahkota Dewa Phaleria macrocarpa (Scheff) Boerl. Artikel disajikan dalam Simposium PERHIPBA, Solo 23-24 April 2014.

Freiesleben, S.H \& A.K. Jager. 2014. Correlation between Plant Secondary Metabolites and Their Antifungal Mechanisms-A Review. Medicinal and Aromatic Plants Vol. 3 (2).

Hur, S. J., S. Y. Lee, Y. Kim, I. Choi \& G. Kim. 2014. Effect of Fermentation on The Antioxidant Activity in Plant-Based Foods. Food Chemistry 160: 346-356.

Jeong, M.R, H.Y. Kim \& J.D. Cha. 2009. Antimicrobial Activity of Methanol Extract from Ficus carica Leaves Against Oral Bacteria. J Bacteriol Virol. 39 (2): 97-102.

Khairunnisa, F. \& U. Pato. 2016. Perbandingan Aktivitas Antibakteri Antara Lactobacillus casei subps. casei R-68 Dan 
Lactobacillus casei Komersil Terhadap Staphylococcus aureus FNCC-15 Dan Escherichia coli FNCC-19. Jom FAPERTA Vol (3) 2 : 1-9.

Li, J., S. Xie, S. Ahmed, F. Wang, Y. Gu, C. Zhang, X. Chai, Y. Wu, J. Cai \& G. Cheng. 2017. Antimicrobial Activity and Resistance: Influencing Factor. Frontiers In Pharmacology. Vol. 8: 364.

Megama, O.P. 2016. Pengaruh Lama Waktu Fermentasi Terhadap Total Asam Tertitrasi (TAT), pH dan Karakteristik Tempoyak Menggunakan Starter Basah Lactobacillus casei. Skripsi. Yogyakarta: Universitas Sanata Dharma.

Naland, H. 2008. Kombucha Teh dengan Seribu Khasiat. Jakarta: PT Agro Media Pustaka.

Nurmiati \& E.D. Wijayanti. 2018. Perbandingan Kadar Fenolik Total Antara Seduhan Daun Gaharu Dan Kombucha Daun Gaharu (Aquailaria malaccensis). Journal Cis-Trans (JC-T) Volume 2 (1): 6-11.

Rinihapsari, E. 2008. Fermentasi Kombucha dan Potensinya Sebagai Minuman Kesehatan. Semarang: STIFAR Yayasan Farmasi.

Romaniuk, J.A.H. \& L. Cegelski. 2015. Bacterial Cell Wall Composition and The Influence of Antibiotics by Cell-Wall and Whole-cell NMR. Phil. Trans. R. Soc. B 370: 20150024.

Savoia, D. 2012. Plant-derived Antimicrobial Compounds: Alternatives to Antibiotics. Future Microbial Vol (7) 8: 979 - 990.

Suhardini, P. Nursyam \& E. Zubaidah. 2016. Studi Aktivitas Antioksidan Kombucha Dari Berbagai Jenis Daun Selama Fermentasi. Jurnal Pangan dan Agroindustri:
Universitas Brawijaya Malang, Vol 4 (1): 221-229.

Velicanski, A.S., D.D. Cvetkovic \& J.J., Vulic. 2014. Antioxidant and Antibacterial Activity of the Beverage Obtained by Fermentation of Sweetened Lemon Balm (Melissa officinalis L.) Tea with Symbiotic Consortium of Bacteria and Yeasts. Food and Biotechnology Vol. 52 (4): 420-429.

Widyasari, A. 2016. Aktivitas Antioksidan Dan Organoleptik Kombucha Daun Kelor Dengan Lama Fermentasi Dan Konsentrasi Daun Kelor Yang Berbeda.Skripsi. Surakarta: Universitas Muhammadiyah Surakarta.

Wijayanti, E. D. \& E. Susilowati. 2017. Eksplorasi Ekstrak Etanol Beberapa Tumbuhan Berpotensi Sebagai Antiketombe. Jurnal Riset Sains dan Teknologi. Volume 1 (2): $75-81$.

Wijayanti, E.D. \& N.C.E. Setiawan. 2017. The Effect of Lactic Acid Fermentation on Fig (Ficus carica) Fruit Flavonoid. Journal of Biological Researches, 23 (1), 39-44.

Wijayanti, E. D., N. C. E. Setiawan \& J. P. Cristi. 2017. Effect of Lactic Acid Fermentation on Total Phenolic Content and Antioxidant Activity of Fig Fruit Juice (Ficus carica). Advances in Health Sciences Research (AHSR), volume 2, Atlantis Press.

Witoyo, J.E., S. Amalia, K.N. Putri, M.T. Zain \& D. Wulandari. 2015. Perubahan Biokimia Selama Proses Black Tea. Skripsi. Malang: Universitas Brawijaya.

Yustin, L.J. \& E.D. Wijayanti. 2018. Aktivitas Antioksidan Sari Rimpang Temu Giring (Curcuma heyneana) Terfermentasi Lactobacillus bulgaricus. Journal Cis-Trans (JC-T) Volume 2 (1): 1-5 